\title{
Participation of Th17 and Treg Cells in Pediatric Bronchial Asthma
}

\author{
Yoshiki Yamamoto, ${ }^{a, b}$ Takaharu Negoro, ${ }^{*, c}$ Akiko Wakagi, ${ }^{c}$ Akane Hoshi, ${ }^{c}$ \\ Alison H. Banham, ${ }^{d}$ Giovanna Roncador, ${ }^{e}$ Haruyo Akiyama, ${ }^{c}$ Takashi Tobe,${ }^{f}$ \\ Susumu Sunaga, ${ }^{a}{ }^{\text {Yasuko Nakano, }}{ }^{c}$ and Kazuo Itabashi ${ }^{b}$
}

\begin{abstract}
${ }^{a}$ Department of Pediatrics, Tokyo Metropolitan Health and Medical Treatment Corporation Ebara Hospital, 4-5-10 Higashiyukigaya, Ota-ku, Tokyo 145-0065, Japan, ${ }^{b}$ Department of Pediatrics, School of Medicine and ${ }^{c}$ Department of Pharmacogenomics, School of Pharmacy, Showa University, 1-5-8 Hatanodai, Shinagawa-ku, Tokyo 142-8555, Japan, ${ }^{d}$ Nuffield Department of Clinical Laboratory Sciences, University of Oxford, Level 4 Academic Block, John Radcliffe Hospital, Headington, Oxford, OX3 9DU, UK, ${ }^{e}$ Monoclonal Antibodies Unit, Biotechnology Program, Centro Nacional de Investigaciones Oncolo'gicas (CNIO), C/Melchor Ferández, Almagro, 3, E-28029, Madrid, Spain and ${ }^{f}$ Center of Pharmaceutical Education, School of Pharmacy, Showa University, 1-5-8 Hatanodai, Shinagawa-ku, Tokyo 142-8555, Japan
\end{abstract}

(Received May 25, 2010; Accepted June 29, 2010; Published online July 2, 2010)

\begin{abstract}
The immune response plays an important role in the development of allergic diseases. It is established that a complex network of various immunocytes such as Th2, non-Th2 (Th17), and regulatory $\mathrm{T}$ (Treg) participate in allergic reactions. In this study, we examined the frequencies of Th17 cells (IL-17-positive cells) and Treg cells (FOXP3-positive cells) in the peripheral blood and elucidated their participation in pediatric allergic diseases such as bronchial asthma and food allergies. Our study included 35 subjects, 27 with allergic diseases (19 with asthma and 8 with food allergies) and 8 were controls (without any allergic diseases); their age ranged from 1 to 13 years. The frequency of Th17 cells (IL-17-positive cells) among the $\mathrm{CD} 4^{+} \mathrm{T}$ cells in the peripheral blood was $2.33 \pm$ $1.29 \%$ in patients with bronchial asthma, $1.53 \pm 1.34 \%$ in those with food allergies, and $1.50 \pm 0.809 \%$ in controls. These results indicated that only the patients with bronchial asthma had a trend towards a higher frequency of Th17 cells $(p=0.1558)$. The ratio of Th17 cells to Treg cells did not show any statistical correlation among the patients with bronchial asthma. However, when we excluded the patients with a severe type of asthma, we could obtain an inverse trend between the ratio of Th17 cells to Treg cells $(p=0.1655)$. This study suggested that Th17 cells and Treg cells participate in pediatric allergic reactions such as bronchial asthma.
\end{abstract}

Key words — regulatory T cells, Th17, FOXP3, IL-17, allergy

\section{INTRODUCTION}

The prevalence of bronchial asthma shows great regional disparity, with a trend toward higher prevalence in more developed regions, i.e., more hygienic communities. Akashi et al. and others ${ }^{1,2)}$ reported that asthma prevalence showed a 2-fold regional variation in Japan, while the International Study of Asthma and Allergies in childhood (ISAAC) Steering Committee ${ }^{3,4)}$ reported that global prevalence varies widely from $1.6 \%$ to $36.8 \%$.

*To whom correspondence should be addressed: Department of Pharmacogenomics, School of Pharmacy, Showa University, 1-5-8 Hatanodai, Shinagawa-ku, Tokyo 142-8555, Japan. Tel.: +81-3-3784-8031; Fax: +81-3-5749-7319; E-mail: tanego@pharm.showa-u.ac.jp
On the other hand, the prevalence of food allergies was reported to be $3.5-4 \%$ (5-10\% during infancy and 1-2\% during childhood) in Japan ${ }^{5)}$ and $\left.3.5-4 \%{ }^{6}\right)(6 \%$ in children below 3 years of age ${ }^{7,8)}$ ) in the U.S.A. Allergic diseases have now become much more common, especially in industrialized countries, and their incidence seems to be increasing worldwide. The rise in the prevalence of allergies and asthma is considered to be a direct and unintended result of the success of modern hygienic practices in preventing childhood infections. Strachan ${ }^{9)}$ suggested that this rise in the prevalence could be due to "the imbalance of Th1/Th2," and his "hygiene hypothesis" has been widely accepted. However, allergic reactions are quite complicated and sometimes difficult to un- 
derstand using a simple hypothesis. For example, the number of patients with Th1 diseases such as Crohn's disease and rheumatoid arthritis have also increased recently, and $\mathrm{Th} 2$, but not $\mathrm{Th} 1$, is induced by a stimulus of a low concentration of toll-like receptor 3 (TLR3), which forms a complex with double-stranded RNA. ${ }^{10)}$ Furthermore, immune T cells other than Th1 and Th2 have been found to exhibit a close relationship with the recent increase in autoimmune diseases.

Regulatory $\mathrm{T}$ cells (Treg cells) are a specialized subpopulation of $\mathrm{T}$ cells that suppress the activation of the immune system and thereby maintain both the homeostasis of the immune system and tolerance to self-antigens. In 1995, Sakaguchi et al. ${ }^{11)}$ found that Tregs had a $\mathrm{CD} 4{ }^{+} \mathrm{CD} 25^{+}$immunophenotype and subsequent studies have identified that FOXP3 was its master regulatory gene. ${ }^{12-14)}$ Tregs account for about $10 \%$ of $\mathrm{CD}^{+} \mathrm{T}$ cells in the peripheral blood and consist of 2 major classes: the thymusderived naturally occurring Treg and peripheraldifferentiated adaptive Treg. Naturally occurring Tregs are important for maintaining self-tolerance, while the adaptive Tregs are thought to be induced in the periphery where they regulate immune responses at local inflammatory sites. ${ }^{13,14)}$

Th17 cells, which are considered developmentally distinct from Th1 and Th2 cells, were found to be a subset of Th cells, which participate in the increased prevalence of allergies and asthma. Infante-Duarte et al. ${ }^{15)}$ first reported that Th17 cells were IL-17-secreting $\mathrm{T}$ cells in 2000 . IL-17 induces the production of inflammatory cytokines or chemokines, which increases neutrophil recruitment into tissues and promotes revascularization. Thus, Th17 is related to various inflammatory or autoimmune diseases such as bacteriosis, scabies, bronchial asthma, articular rheumatisms, systemic lupus erythematosus (SLE), multiple sclerosis, and transplantation tolerance.

In the present study, we determined the frequency of both Th17 cells and Treg cells in the peripheral blood of pediatric patients with bronchial asthma and food allergies. Our results suggest that Th17 cells and Tregs participate in the pediatric allergic reactions such as bronchial asthma.

\section{MATERIALS AND METHODS}

Subjects — Our subjects were 35 children who had visited the Department of Pediatrics, Tokyo
Metropolitan Health and Medical Treatment Corporation Ebara Hospital, between July 2006 and March 2007. Twenty-seven of these patients had been diagnosed with allergosis: 19 patients had asthma and 8 had food allergies. The 8 patients without any allergic diseases served as controls. The study was approved by the Clinical Research Committee of Tokyo Metropolitan Health and Medical Treatment Corporation Ebara Hospital and the Ethics Committee of Showa University, including third-party specialists. We collected the following clinical data from each subject, including the controls: age, gender, diagnosis, family history of allergies, anamnesis, medication list, duration of illness, total serum IgE values, allergen-specific IgE values [radioallergosorbent test (RAST) scores for ticks, dogs, cats, ciders, milk, egg white, wheat, soybeans, Alternaria, Candida, etc.], and vaccination history (Tables 1-3).

Patients with bronchial asthma were classified according to the frequency of symptoms (on the basis of Japanese Pediatric Guideline for The Treatment and Management of Asthma 2008) as follows: intermittent, mild, moderate, and severe types. Patients with the intermittent type of asthma showed seasonal and intermittent coughing with a light wheeze that was easily suppressed by the administration of $\beta_{2}$-agonists. Patients with the mild type showed non-persistent coughing with a light wheeze that occurred more than once a month but less than once a week, and it was sometimes accompanied by difficulty in breathing. Patients with the moderate type of asthma showed persistent coughing with a light wheeze that occurred more than once a week, which was sometimes accompanied by moderate or severe attacks. Patients with the severe type of asthma, who usually have a difficulty in daily life, suffer from persistent coughing with a wheeze several times a week, and on a few times, it is accompanied by moderate or severe, often irremediable, attacks.

We defined recovery from food allergies as the disappearance of the allergic eczema after removal of the corresponding allergen from the patient who

Table 1. Clinical Characteristics of Patients with Bronchial Asthma (BA), Food Allergy (FA) and Controls

\begin{tabular}{lrcc}
\hline \hline Subjects & $n$ & Male/Female & Age (years) \\
\hline BA & 19 & $13 / 6$ & $7.5(2-13.8)$ \\
FA & 8 & $7 / 1$ & $2.6(1.2-7.9)$ \\
Control & 8 & $6 / 2$ & $2.4(1.3-7.4)$ \\
\hline
\end{tabular}


had previously shown immediate or chronic allergic reactions after ingestion of the causal food.

Allergen-specific RAST scores were determined using the $\operatorname{IgE}$ values, which were classified as follows: Class 0 (less than $0.34 \mathrm{IU} / \mathrm{ml}$ ), Class 1 (0.35-0.69 IU/ml), Class $2(0.7-3.49 \mathrm{IU} / \mathrm{ml})$, Class $3(3.50-17.4 \mathrm{IU} / \mathrm{ml})$, Class $4(17.5-49.9 \mathrm{IU} / \mathrm{ml})$, Class 5 (50.05-99.9 IU/ml), and Class 6 (more than $100 \mathrm{IU} / \mathrm{ml})$.

Patients with asthma included 13 boys and 6 girls (average age: 7.5 years, ranging from 2 to 13.8 years, Table 1). They were classified in terms of disease severity into 4 groups: 4 patients were of the intermittent type, 5 patients were of the mild type, 4 patients were of the moderate type, and 6 patients were of the severe type. The periods during which the patients suffered from asthma ranged from 0.6 to 10.3 years, with an average duration of 3.8 years. Inhalational corticosteroids (ICS) were prescribed for 6 patients; intermittent-type patients received no medication, mild-type patients received an average dose of $75 \mu \mathrm{g} /$ day, moderate-type patients received an average dose of $225 \mu \mathrm{g} /$ day, and severe-type patients received an average dose of $433 \mu \mathrm{g} /$ day. Complications occurred in 3 patients: atopic dermatitis in 2 and allergic rhinitis in 1 (Table 2).

Patients with food allergies comprised 7 boys and 1 girl (average age: 2.6 years, ranging from 1.2 to 7.9 years, Table 1). Six patients exhibited atopic dermatitis, whereas no complications occurred in the other 2 patients. Serum IgE values ranged from 45.1 to $1188 \mathrm{IU} / \mathrm{ml}$, with an average of $189.5 \mathrm{IU} / \mathrm{ml}$. One patient was allergic to only 1 food, but the other 7 patients were allergic to many foods. The allergypositive foods were eggs for all, milk for 6 , wheat for 5 , peanuts for 3 and soybeans for 2 patients (Table 3).

Preparation of Peripheral Blood Mononuclear Cells (PBMC) — Blood samples (4-14 ml) were drawn using an evacuated single-use test tube and were suspended in the same volume of phosphate buffered saline (PBS). This suspension was carefully layered on $5 \mathrm{ml}$ of Lymphoprep and was then successively centrifuged at $500 \mathrm{rpm}$ for $5 \mathrm{~min}$, $1500 \mathrm{rpm}$ for $3 \mathrm{~min}$, and $3600 \mathrm{rpm}$ for $20 \mathrm{~min}$ at room temperature. The mononuclear leukocyte layer obtained was collected and centrifuged at $1200 \mathrm{rpm}$ for $10 \mathrm{~min}$ at $4^{\circ} \mathrm{C}$. The pellet was suspended in $5 \mathrm{ml} \mathrm{PBS}$, which was used as the PBMC solution.

Detection of Intracellular FOXP3 — The suspension containing $1 \times 10^{6}$ cells of the purified PBMCs $\left(\mathrm{CD}^{+} \mathrm{T}\right.$ cells $)$ was centrifuged at $1800 \mathrm{rpm}$ for $10 \mathrm{~min}$ at $4^{\circ} \mathrm{C}$. FOXP3-staining method was in accordance with the previous report. ${ }^{16)}$ The pellet was suspended in $1 \mathrm{ml}$ of FOXP3-staining so-

Table 2. Clinical Characteristics of Asthma Patients

\begin{tabular}{|c|c|c|c|c|c|c|c|c|}
\hline No. & Age & Gender & $\begin{array}{l}\text { Classification } \\
\text { (based on } \\
\text { severity) }\end{array}$ & $\begin{array}{l}\text { Duration of } \\
\text { asthma (years) }\end{array}$ & $\begin{array}{c}\text { ICS } \\
(\mu \mathrm{g} / \text { day })\end{array}$ & $\begin{array}{c}\text { Serum IgE } \\
(\mathrm{IU} / \mathrm{ml})\end{array}$ & $\begin{array}{l}\text { RAST } \\
\text { Score } \\
\text { (mite) }\end{array}$ & Complication \\
\hline 1 & 4.9 & $\mathrm{~F}$ & mild & 2.9 & 75 & 1007 & 6 & - \\
\hline 2 & 6.4 & M & intermittent & 4.4 & - & 254 & 2 & - \\
\hline 3 & 7.2 & M & intermittent & 2.1 & - & 381 & 3 & - \\
\hline 4 & 4.9 & M & mild & 1.6 & 100 & 75 & 4 & - \\
\hline 5 & 5.8 & M & intermittent & 2.6 & - & 3186 & 6 & - \\
\hline 6 & 4.3 & M & mild & 1.3 & - & 3373 & 6 & - \\
\hline 7 & 5.4 & $\mathrm{~F}$ & moderate & 4.9 & 200 & 346 & 5 & - \\
\hline 8 & 9.9 & M & intermittent & 6.9 & - & 1766 & 6 & AR \\
\hline 9 & 10.8 & M & severe & 10 & 200 & 937 & 6 & $\mathrm{AD}$ \\
\hline 10 & 13.8 & $\mathrm{~F}$ & severe & 10.3 & 800 & 108 & 4 & - \\
\hline 11 & 8.5 & M & mild & 7 & 200 & 1311 & 6 & - \\
\hline 12 & 2 & M & mild & 0.9 & - & 681 & 2 & - \\
\hline 13 & 7.5 & M & moderate & 2.5 & 100 & 4149 & 6 & $\mathrm{AD}$ \\
\hline 14 & 5.7 & M & moderate & 3.9 & 200 & 2528 & 6 & - \\
\hline 15 & 16.2 & $\mathrm{~F}$ & severe & 8.3 & 400 & 902 & 6 & - \\
\hline 16 & 7.5 & M & moderate & 0.6 & 400 & 1390 & 6 & - \\
\hline 17 & 11.4 & $\mathrm{~F}$ & severe & 2.4 & 400 & 556 & 5 & - \\
\hline 18 & 13.3 & M & severe & 10.3 & 400 & 3959 & 6 & - \\
\hline 19 & 10 & $\mathrm{~F}$ & severe & 9 & 400 & 981 & 5 & - \\
\hline
\end{tabular}

AD: atopic dermatitis, AR: allergic rhinitis. 
Table 3. Clinical Characteristics of Patients with Food Allergy

\begin{tabular}{cccccl}
\hline \hline No. & Age (years) & Gender & Complication & Serum IgE (IU/ml) & \multicolumn{1}{c}{ Allergen } \\
\hline 1 & 1.2 & M & - & 45.1 & eggs, milk \\
2 & 7.9 & M & AD & 1188 & eggs, milk, wheat, peanuts \\
3 & 5.8 & M & AD & 606 & eggs, milk, wheat, soy, peanuts \\
4 & 2.4 & F & AD & 57 & eggs, milk, wheat, soy, peanuts \\
5 & 3.2 & M & AD & 258 & eggs, wheat \\
6 & 1.9 & M & AD & 114 & eggs \\
7 & 2.3 & M & AD & 121 & eggs, milk \\
8 & 2.8 & M & - & 681 & eggs, milk, wheat, soy \\
\hline
\end{tabular}

lution [consisted of PBS, $0.5 \%$ bovine serum albumin (BSA), $2 \mathrm{mM}$ EDTA and $0.5 \%$ Tween 20] and kept overnight at $4{ }^{\circ} \mathrm{C}$. After centrifugation, the pellet was suspended in $1 \mathrm{ml}$ of deoxyribonuclease (DNase) I solution and incubated for $30 \mathrm{~min}$ at $37^{\circ} \mathrm{C}$. After washing with the FOXP3-staining solution, treatment with DNase I was repeated, and the pellet was washed again with the FOXP3-staining solution. The pellet was blocked for $30 \mathrm{~min}$ with $100 \mu \mathrm{l}$ of $30 \%$ goat serum that had been diluted with the FOXP3-staining solution. After centrifugation, the pellet was diluted 25 times of the original PBMC solution with the FOXP3-staining solution containing $30 \%$ goat serum. One hundred microliters of mouse anti-human FOXP3 (259D) hybridoma supernatant was added to the mixture, which was incubated for 50-60 min at room temperature and then washed twice with the FOXP3-staining solution.

Alexa 488-labeled goat anti-mouse IgG $(\mathrm{H}+\mathrm{L})$ was used as the secondary antibody. Secondary antibody solution $(100 \mu \mathrm{l})$ that had been diluted 800 times with the FOXP3-staining solution containing $30 \%$ goat serum was added and then incubated for $1 \mathrm{hr}$ at room temperature. It was then washed twice with the FOXP3-staining solution.

The cell-surface antigens of PBMCs were detected using the procedures described herein. After blocking for 30 min with $100 \mu \mathrm{l}$ of $10 \%$ goat serum, the pellet obtained by centrifugation was reacted for 15 min at room temperature with PE-Cy5 (PC5)labeled anti-human CD4 (12 $\mu$ l, Beckman Coulter, Brea, CA, U.S.A.). It was then washed with the FOXP3-staining solution.

Detection of IL-17 in T Cells - The suspension containing $1 \times 10^{6} \mathrm{PBMCs}\left(\mathrm{CD}^{+}{ }^{+} \mathrm{T}\right.$ cells) was centrifuged at $1800 \mathrm{rpm}$ for $15 \mathrm{~min}$ at $4^{\circ} \mathrm{C}$. The pellet was suspended in $1 \mathrm{ml}$ of RPMI 1640 containing $10 \%$ fetal bovine serum (FBS) and Streptmycin/Penicillin (SM/PC). After addition of ionomycin (final concentration, $2 \mu \mathrm{g} / \mathrm{ml}$ ), phorbol myristate acetate (PMA, final concentration, $40 \mathrm{ng} / \mathrm{ml}$ ), and brefeldin A (final concentration, $40 \mu \mathrm{g} / \mathrm{l}$ ), the suspension was incubated at $37^{\circ} \mathrm{C}$ for $4 \mathrm{hr}$ with stirring $(200 \mathrm{rpm})$ under $5 \% \mathrm{CO}_{2}$ atmosphere in a polystyrene round tube ( $5 \mathrm{ml}$, Falcon BD 352058 ). The cells were collected and washed twice with the FOXP3-staining solution.

Intracellular FOXP3 was labeled with the fluorescent marker by the in-column staining of cells. The pellet obtained after the final washing, as described above, was then blocked for $30 \mathrm{~min}$ with $100 \mu \mathrm{l}$ of $30 \%$ goat serum. After washing, the cell-surface antigen and cytokine were reacted for $20 \mathrm{~min}$ at room temperature with various antibodies, such as PC5-labeled anti-human CD4 (12 $\mu \mathrm{l})$ and Phycoerythrin (PE)-labeled anti-human IL-17 (20 $\mu 1$, eBioscience, San Diego, CA, U.S.A.) and then washed with FOXP3-staining solution.

IL-17-positive cells in the peripheral blood were detected by stimulating with ionomycin and PMA (an activating reagent for $\mathrm{T}$ cells). In humans, it has been reported that transient FOXP3 expression was enhanced by TCR stimulation, ${ }^{17)}$ this was also observed in our samples as illustrated in Fig. 1a. To avoid artificially increasing the frequency of FOXP3 expression in peripheral blood the FOXP3 data was obtained under unstimulated conditions.

Flow Cytometry — The samples, which were suspended in $350 \mu \mathrm{l}$ of the FOXP3-staining buffer solution, were subjected to flow cytometry (EPICS XL, Beckman Coulter) and analyzed by Flow Jo software. The signals from debris, red cells, and dead cells were removed by forward (FS) or sideward (SS) scatterings.

Statistical Analysis — Statistical analysis of the data was performed with JMP software (SAS Institute, Cary, NC, U.S.A.). The variance of the data was calculated by analysis of variance (ANOVA) or Welch methods. The difference between the 2 groups was estimated by Student's $t$-test. The correlation between the 2 variables was obtained with Pearson's coefficient. 

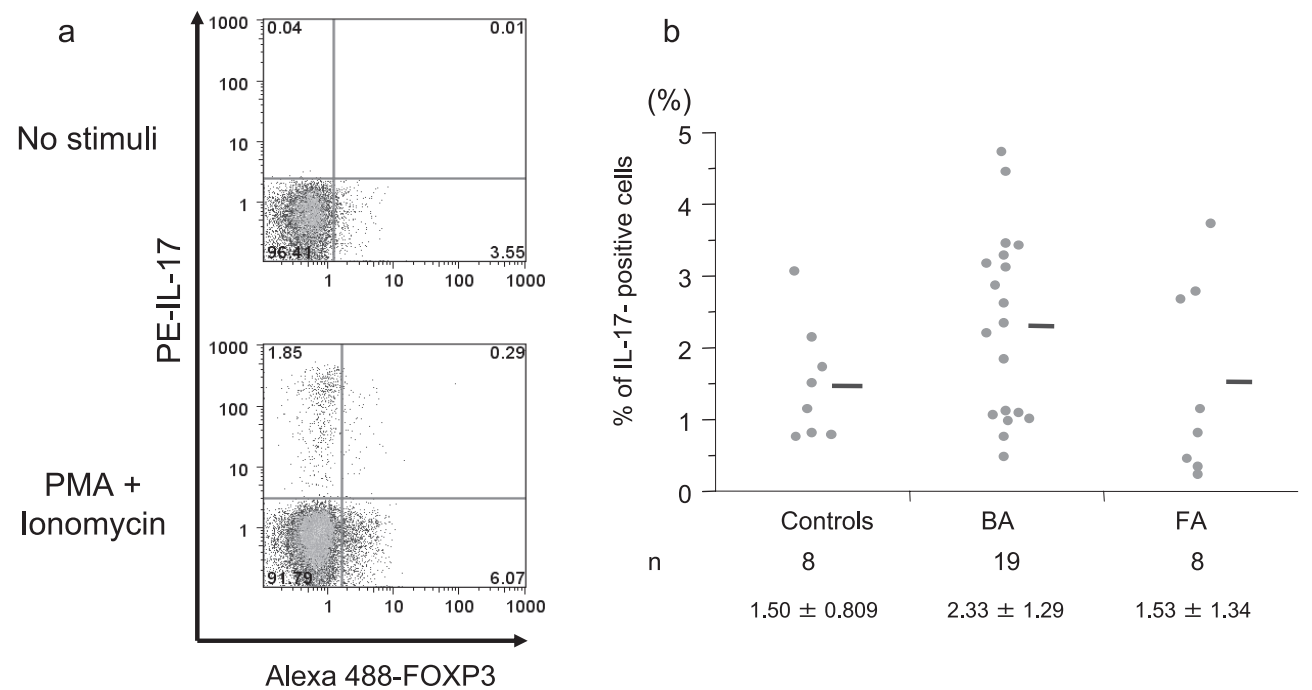

Fig. 1. Frequencies of IL-17-positive Cells in Patients with Asthma or Food Allergies

PBMCs in the peripheral blood were stained with PC5-CD4, PE-IL17, or Alexa 488-FOXP3 4-6 hr after stimulation with or without PMA + Ionomycin. (a) A typical plot of IL-17-positive cells determined by flow cytometry. (b) Frequency of IL-17-positive cells in CD4 ${ }^{+} \mathrm{T}$ cells compared with patients with asthma (BA) or with food allergies (FA). $p=0.1558$ (ANOVA).
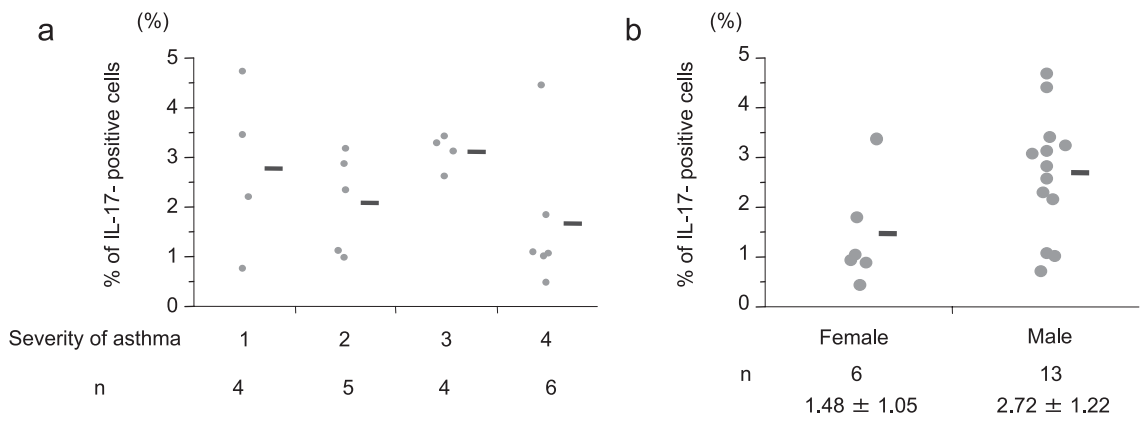

Fig. 2. Frequencies of IL-17-positive Cells Related to Severity of Asthma or Male/Female Difference

PBMCs in the peripheral blood were stained with PC5-CD4, PE-IL17, or Alexa 488-FOXP3 4-6 hr after stimulation with or without PMA + Ionomycin. (a) Correlation with the severity of asthma. The severity of asthma is as follows: 1 , Intermittent; 2 , mild; 3 , moderate; and 4, severe. (b) The frequency of IL-17-positive cells between the male and female patients.

\section{RESULTS}

\section{Frequency of IL-17-positive and FOXP3-positive Cells in the Peripheral Blood}

Patients with Asthma: Figure 1a shows a typical correlation plot of the frequencies of IL-17positive and FOXP3-positive cells, which were detected by double staining of the cells. Thus, it could be showed the frequency of $\mathrm{IL}_{1} 7^{+} \mathrm{FOXP} 3^{-} \mathrm{T}$ cells. Patients with asthma showed rather higher frequencies of IL-17-positive cells $(2.33 \pm 1.29 \%)$ than the controls $(1.50 \pm 0.809 \%$, Fig. 1b). Severe-type patients tended to show lower frequencies (Figs. 2a and 3a: $p=0.3182$, Fig. 3b: $p=0.1655$ ). The disease duration did not significantly affect the frequency, although patients with asthma consistently exhibited higher frequencies than controls (Fig. 4).

FOXP3 is the master regulatory gene of Treg and can be used as a specific marker for Treg. The frequency of FOXP3-positive cells (Treg cells) in unstimulated PBMCs was similar between the asthma patients $(4.34 \pm 0.359 \%)$ and the controls $(3.85 \pm 0.553 \%)$. We compared the ratio of IL17-positive cells (Th17 cells) in stimulated PBMCs with FOXP3-positive cells (Treg cells) in unstimulated PBMCs. A slight trend towards an inverse correlation was obtained in the asthma patients (Fig. 3a, $r=-0.2420, p=0.3182$ ). By excluding the severetype of patients who showed a low frequency of IL17-positive cells (Fig. 3a), we increased the trend towards an inverse correlation between percentages of IL-17-positive cells and FOXP3-positive cells 


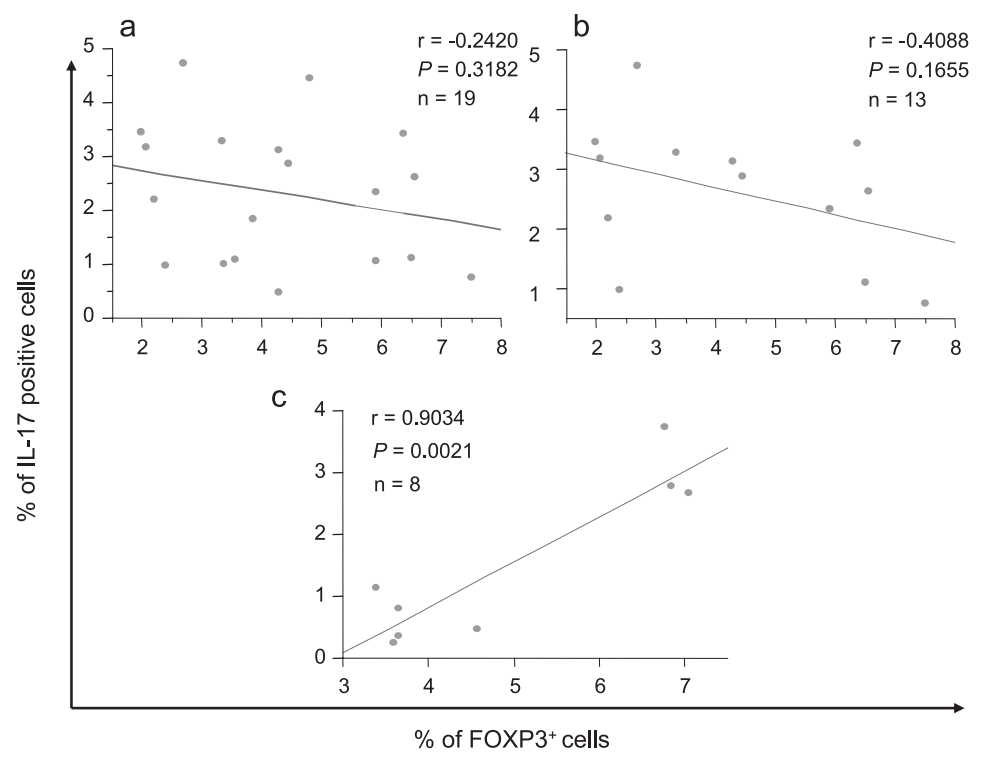

Fig. 3. Correlation between the Frequencies of IL-17-positive Cells and FOXP3-positive Cells in Patients with Asthma and Food Allergies

PBMCs in the peripheral blood were stained with PC5-CD4, PE-IL17, or Alexa 488-FOXP3 4-6 hr after stimulation with or without PMA + Ionomycin. (a) All the patients with asthma. (b) Patients with the severe type excluded. (c) Patients with food allergies. Correlation between the frequencies of IL-17-positive cells in stimulated PBMCs and FOXP3-positive cells in unstimulated PBMCs was estimated by Pearson's coefficient.

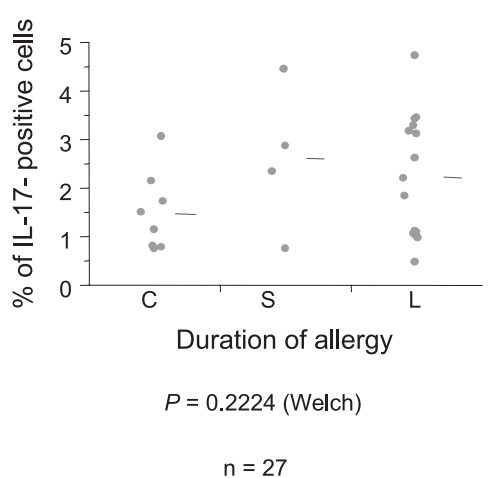

Fig. 4. Relationship between IL-17-positive Cells and Disease Duration in Asthma Patients

$\mathrm{C}$, control; S, disease duration less than 2 years; L, disease duration more than 2 years.

(Fig. 3b, $r=-0.4088, p=0.1655$ ).

Patients with Food Allergy: The frequency of the IL-17-positive cells was $1.53 \pm 1.34 \%$ in the food allergy patients, which was almost the same as that of the controls (Fig. 1b, $p=0.1558$ ). The frequency of the FOXP3-positive cells was $4.95 \pm$ $0.553 \%$ in the food allergy patients, which was a little higher than that of the controls. The frequencies of the IL-17-positive cells and those of the FOXP3positive cells showed a strong positive correlation in the food allergy patients (Fig. 3c, $r=0.9034$, $p=0.0021)$.

\section{DISCUSSION}

Asthma originates from the immune responses induced by Th2 cells. Th2 cells secrete cytokines that accelerate IgE production and activate eosinophilic leukocytes, eventually causing a predisposition toward chronic inflammation of the lungs where the airways (bronchi) are reversibly narrowed. Recently, a close relationship between IL-17 and allergic diseases was reported in which; that is, IL-17 accelerated the production of cytokines such as IL-6, IL-8, and Chemokine (C-X$\mathrm{C}$ motif) ligand (CXCL) 1 from bronchial fibroblasts or epithelial cells, thereby inducing a positive neutrophil chemotaxis followed by chronic inflammation. ${ }^{18,19)}$ In addition, Cheung et al. reported that human eosinophils constantly expressed receptors such as IL-17RA/RC (to IL-17A, F) and IL23R (to IL-23) and that IL-17- and/or IL-23stimulated eosinophils secreted both chemokines such as CXCL1, CXCL8, and CCL4 as well as cytokines such as IL-1 $\beta$, IL-6, and IL-17/IL-23. ${ }^{20)}$ Furthermore, the differentiation of human Th17 was promoted by a combination of cytokines such as IL- $1 \beta+$ IL-23 and IL- $1 \beta+$ IL- 6 without any participation of TGF- $\beta$, as against the case in mice. ${ }^{21,22)} \mathrm{IL}$ 17 and IL-23, which are secreted by dendritic cells or macrophages, affect eosinophilic leukocytes and promote the production of cytokines/chemokines 
together with new Th17 cells causing a vicious cycle that ultimately worsens the allergic inflammation. ${ }^{23)}$ It has also been reported that IL-17 participated in the manifestation of atopic dermatitis in its acute phase, which is induced either by $\mathrm{Th} 2$ when acute or by Th1 when chronic. ${ }^{24)}$

Our results suggest the participation of Th17 cells during the onset of bronchial asthma even in its early stage, since the frequency of Th17 cells was always high in the peripheral blood independent of disease duration (Fig. 4). A negative correlation was obtained between the frequencies of Th17 and Treg cells after excluding patients with severe type of asthma ( $p=0.1655$, Fig. $3 b)$. The reason why the frequencies of both Th17 and Treg cells in the severe type of patients were as low as those in the controls might be due to the high dose of ICS ( $433 \mu \mathrm{g} / \mathrm{day})$ prescribed for severe-type patients, which indicates that steroids could suppress the expression of these cells. The frequency of IL17-positive cells differed significantly between the male and female patients (Fig. 2b). This might be due to developmental differences in respiratory organs because the average age of females in our study was 3 years more than that of male patients.

Shreffler et al. reported that patients with a milk allergy who acquired tolerance to heated milk exhibited a higher frequency of Treg cells that reacted specifically with the antigen in milk than did patients who did not acquire this tolerance for heated milk and that the former usually showed mild allergy symptoms and convalesced satisfactorily. ${ }^{23)}$ It was also reported that the frequency balance between Th17 cells and Treg cells was important in the suppression of intestinal inflammation and that IL-23 promoted the differentiation of Th17 cells and suppressed the induction of Treg cells. ${ }^{25}$ )

Our results indicated that the frequencies of both Th17 and Treg cells were substantially higher in 3 of the 8 patients with food allergies than those in the controls (Figs. $1 \mathrm{~b}$ and $3 \mathrm{c}$ ). The symptoms of the other 5 patients were easily relieved by the subsequent medical treatment, indicating that the frequencies of both cell types in these patients were similar to those in the controls. Positive trend was shown between the frequencies of Th17 and Treg cells in the patients with food allergies (Fig. 3c), which was in contrast to the negative correlation observed in the patients with asthma (Fig. 3a and 3b). This might be due to differences between bronchial and intestinal inflammation. However, a few cases showed high frequency of FOXP3-positive and IL- 17-positive cells, even among the asthma patients. Our study was performed using a limited number of subjects and thus its robustness should be further investigated in a larger study.

Deknuydt et al. ${ }^{26)}$ and Voo et al. ${ }^{27)}$ found that Treg cells could be converted into Th17 cells in the inflammatory tissues by a Th17 cell stimulation in the presence of IL-2. This conversion was accomplished using both the natural naive Treg cells and memory $\mathrm{T}$ cells. This phenomenon suggests a partial conversion of FOXP3-positive cells into IL-17producing cells in the inflammatory tissues as a way to balance the activities of Th17 and Treg cells.

Thus, in the present study, we elucidated the participation of Th17 and Treg cells in pediatric patients with bronchial asthma or food allergies. To further clarify the immunological functions of these 2 cells, it will be necessary to examine many more cases of allergic diseases, including asthma, food allergies, atopic dermatitis, allergic rhinitis, and others.

Acknowledgement This work was supported in part by a Grant-in-Aid from the Ministry of Education, Culture, Sports, Science, and Technology of Japan (\#21591288) and "High-Tech Research Center" Project for Private Universities: matching fund subsidy from MEXT (Ministry of Education, Culture, Sports, Science and Technology) of Japan, 2005-2009.

\section{REFERENCES}

1) Akashi, M. and Akasawa, A. (2007) Study about all age rank nation-wide surveys about prevalence/morbidity of bronchial asthma and QOL. Jpn. Soc. Pediatr. Allergy Clin. Immunol., 21, 743748.

2) Japanese Society of Pediatric Allergy and Clinical Immunology (2009) Japanese Pediatric Guideline for the Treatment and Management of Asthma, Kyowa Kikaku, pp. 38-42.

3) Asher, M. I., Montefort, S., Björkstén, B., Lai, C. K., Strachan, D. P., Weiland, S. K. and Williams, H. (2006) Worldwide time trends in the prevalence of symptoms of asthma, allergic rhinoconjunctivitis, and eczema in childhood: ISAAC Phases One and Three repeat multicountry cross-sectional surveys. Lancet, 368, 733-743.

4) The International Study of Asthma and Allergies in childhood (ISAAC) steering committee (1998) Worldwide variation in the prevalence of asthma 
symptoms: The International Study of Asthma and Allergies in childhood (ISAAC). Eur. Respir. J., 12, 315-335.

5) Japanese Society of Pediatric Allergy and Clinical Immunology (2005) Japanese Pediatric Guideline for Food Allergy, Kyowa Kikaku, pp. 8-11.

6) Munoz-Furlong, A., Sampson, H. A. and Sicherer, S. H. (2004) Prevalence of self-reported seafood allergy in the U.S. J. Allergy Clin. Immunol., 113, S100.

7) Woods, R. K., Abramson, M., Bailey, M. and Walters, E.H. (2001) International prevalence of reported food allergies and intolerances. Comparisons arising from the European Community Respiratory Health Survey (ECRHS) 1991-1994. Eur. J. Clin. Nutr., 55, 298-304.

8) Rance, F., Kanny, G., Dutau, G. and MoneretVautrin, D. A. (1999) Food hypersensitivity in children: clinical aspect and distribution of allergens. Pediatr. Allergy Immunol., 10, 33-38.

9) Strachan, D. P. (1989) Hay fever, hygiene, and household size. BMJ, 299, 1259-1260.

10) Jeon, S. G., Oh, S. Y., Park, H. K., Kim, Y. S., Shim, E. J., Lee, H. S., Oh, M. H., Bang, B., Chun, E. Y., Kim, S. H., Gho, Y. S., Zhu, Z., Kim, Y. Y. and Kim, Y. K. (2007) Th2 and Th1 lung inflammation induced by airway allergen sensitization with low and high doses of double-stranded RNA. J. Allergy Clin. Immunol., 120, 803-812.

11) Sakaguchi, S., Sakaguchi, N., Asano, M., Itoh, M. and Toda, M. (1995) Immunologic self-tolerance maintained by activated T cells expressing IL-2 receptor alpha-chains (CD25). Breakdown of a single mechanism of self-tolerance causes various autoimmune diseases. J. Immunol., 155, 1151-1164.

12) Fontenot, J. D., Gavin, M. A. and Rudensky, A. Y. (2003) Foxp3 programs the development and function of CD4+CD25+ regulatory T cells. Nat. Immunol., 4, 330-336.

13) Hori, S., Nomura, T. and Sakaguchi, S. (2003) Control of regulatory $\mathrm{T}$ cell development by the transcription factor Foxp3. Science, 299, 1057-1061.

14) Bacchetta, R., Gambineri, E. and Roncarolo, M. G. (2007) Role of regulatory T cells and FOXP3 in human diseases. J. Allergy Clin. Immunol., 120, 227235.

15) Infante-Duarte, C., Horton, H. F., Byne, M. C. and Kamradt, T. (2000) Microbial lipopeptides induce the production of IL-17 in Th cells. J. Immunol., $\mathbf{1 6 5}, 6107-6115$.

16) Roncador, G., Brown, P. J., Maestre, L., Hue, S., Martínez-Torrecuadrada, J. L., Ling, K. L., Pratap, S., Toms, C., Fox, B. C., Cerundolo, V., Powrie, F. and Banham, A. H. (2005) Analysis of FOXP3 protein expression in human $\mathrm{CD} 4{ }^{+} \mathrm{CD} 25^{+}$regulatory $\mathrm{T}$ cells at the single-cell level. Eur. J. Immunol., 35, 1681-1691.

17) Banham, A. H., Powrie, F. M. and Suri-Payer, E. (2006) FOXP3+ regulatory T cells: Current controversies and future perspectives. Eur. J. Immunol., 36, 2832-2836.

18) Molet, S., Hamid, Q., Davoine, F., Nutku, E., Taha, R., Pagé, N., Olivenstein, R., Elias, J. and Chakir, J. (2001) IL-17 is increased in asthmatic airways and induces human bronchial fibroblasts to produce cytokine. J. Allergy Clin. Immunol., 108, 430-438.

19) Kawaguchi, M., Kokubu, F., Kuga, H., Matsukura, S., Hoshino, H., Ieki, K., Imai, T., Adachi, M. and Huang, S. K. (2001) Modulation of bronchial epithelial cells by IL-17. J. Allergy Clin. Immunol., 108, 804-809.

20) Cheung, P. F., Wong, C. K. and Lam, C. W. (2008) Molecular mechanisms of cytokine and chemokine release from eosinophils activated by IL-17A, IL17F, and IL-23: implication for Th17 lymphocytesmediated allergic inflammation. J. Immunol., 180, 5625-5635.

21) Wilson, N. J., Boniface, K., Chan, J. R., McKenzie, B. S., Blumenschein, W. M., Mattson, J. D., Basham, B., Smith, K., Chen, T., Morel, F., Lecron, J. C., Kastelein, R. A., Cua, D. J., McClanahan, T. K., Bowman, E. P. and de Waal Malefyt, R. (2007) Development, cytokine profile and function of human interleukin 17-producing helper T cells. Nat. Immunol., 8, 950-957.

22) Acosta-Rodriguez, E. V., Napolitani, G., Lanzavecchia, A. and Sallusto, F. (2007) Interleukins $1 \mathrm{~b}$ and 6 but not transforming growth factor $\beta$ are essential for the differentiation of interleukin 17-producing human T helper cells. Nat. Immunol., 8, 942-949.

23) Shreffler, W. G., Wanich, N., Moloney, M., NowakWegrzyn, A. and Sampson, H. A. (2009) Association of allergen-specific regulatory $\mathrm{T}$ cells with the onset of clinical tolerance to milk protein. J. Allergy Clin. Immunol., 123, 43-52.

24) Koga, C., Kobashima, K., Shiraishi, N., Kobayashi, M. and Tokura, Y. (2008) Possible pathogenic role of Th17 cells for atopic dermatitis. J. Invest. Dermatol., 128, 2625-2630.

25) Ahem, P. P., Lzcue, A., Maloy, K. J. and Powrie, F. (2008) The interleukin-23 axis in intestinal inflammation. Immunol. Rev., 226, 147-159.

26) Deknuydt, F., Bioley, G., Valmori, D. and Ayyoub, M. (2009) IL-1beta and IL-2 convert human Treg into Th17 cells. Clin. Immunol., 131, 298-307. 
27) Voo, K. S., Wang, Y. H., Santori, F. R., Boggiano, C., Wang, Y. H., Arima, K., Bover, L., Hanabuchi, S., Khalili, J., Marinova, E., Zheng, B., Littman, D. R. and Liu, Y. J. (2009) Identification of IL-17producing FOXP3+ regulatory $\mathrm{T}$ cells in humans. Proc. Natl. Acad. Sci. U.S.A., 106, 4793-4798. 